\title{
Study on Exhaust Gas Reduction Technology for Generator
}

\author{
Jung-Hwang Choi ${ }^{1}$ and Doo-Sung Baik ${ }^{2}$ \\ ${ }^{1}$ Ph.D, Senior Research, CMC Tech, Korea \\ ${ }^{2}$ Professor, Computer-aided Mechanical Engineering, Daejin Univ., Korea \\ ${ }^{1}$ dsbaik@daejin.ac.kr
}

\begin{abstract}
The energy produced through biomass, a bio-organism, is called bioenergy. Recently, the amount of biogas generated from food waste is increased, and the development of technology to deal with food waste urgent. The main ingredient fermented from food waste is more than $60 \%$ of methane, and the generation of electricity generated by using cogeneration as fuel is more than 35\% of total energy. However, the amount of NOx generated in the exhaust gas discharged from the power plant using biogas is increased significantly, and a technology for reducing the amount of emission is needed. By applying De-NOx system (SCR) applied to the vehicle, the existing diesel generator was concerted and applied to the generator for bioenergy. As NOx increases, the amount of emissions increases and the temperature of the exhaust gas increases. Especially, NOx is more exhausted and the exhaust gas temperature increases as the exhaust volume increases and in order to improve the purification efficiency, an apparatus for controlling the exhaust gas temperature is required to increase the optimal purification efficiency. This paper aims to develop a technology to improve NOx reduction efficiency when applying SCR to reduce NOx generated by using methane gas in biogas engine.
\end{abstract}

Keywords: Biogas, Bioenergy, Biomass, SCR (Selective Catalytic Reduction), CH4

\section{Introduction}

Biomass refers to bio-organisms, and bioenergy can produce liquid fuels such as ethanol, methanol, and bio-diesel, which are fuels, and produce gaseous fuels such as hydrogen or methane. There are various kinds of biomass on the earth, and livestock manure such as animals and plants and food waste are all possible as biomass. In its raw state, it is possible to produce thermal energy from itself. In addition, it is possible to obtain energy sources such as methane, biodiesel, hydrogen and ethanol through processing, and can be used as biodiesel automobile, ethanol fuel or fuel for power generation [1][2]. Combustion of biomass resources or biochemical processes using microorganisms or bacteria through biomass anaerobic digestion or fermentation, in particular food waste or livestock manure generates gas using bacterial while blocking air [3][4][5]. Biogas is produced from waste disposal using anaerobic digestion of organic matter. It is composed predominantly of methane, carbon dioxide, hydrogen and nitrogen, and can produce enhanced engine performance and reduce emissions compared to conventional fuel such as gasoline or diesel. Natural gas and LPG are easily obtained from petroleum-based fuels but biogas can be available in various sources for

Article history:

Received (September 29, 2019), Review Result (November 2, 2019), Accepted (December 19, 2019) 
example, in waste organic materials. Biogas can be obtained from animal waste or plant matter such as leaves and water hyacinth. Those materials can be digested through the anaerobic process and used as energy sources so called biogas. However, large amount of nitrogen oxides are emitted when the engine is run using biofuels [6]. Two techniques are generally applied to reduce $\mathrm{NO}_{\mathrm{x}}$. Representative technologies are LNT (Lean $\mathrm{NO}_{\mathrm{x}}$ Trap) and SCR (Selective Catalyst Reduction). LNT is a principle that captures $\mathrm{NO}_{\mathrm{x}}$ in lean fuel conditions, which is a general operating area of an engine, and then discharges it in a rich fuel atmosphere to convert it into nitrogen and carbon dioxide by a catalyst. However, in the case of large diesel engines, it is difficult to apply LNT because it is difficult to create rich conditions unlike gasoline engines. In addition, the use of fuel as a reducing agent causes deterioration of fuel efficiency and increase of $\mathrm{CO}_{2}$, and is a device suitable for small passenger cars. SCR is a catalyst that selectively reduces $\mathrm{NO}_{\mathrm{x}}$ in exhaust gas, and most of urea water is used as a reducing agent [7][8][9][10]. In case of industrial engine with constant driving condition, ammonia is used as a reducing agent. However, if driving condition changes every time like a car, the use of ammonia can release the remaining ammonia to the atmosphere, which can be harmful to the human body and environment. In the SCR system, when urea water is supplied from the top of the catalyst, part of the urea water is separated into an ammonia component and occluded in the storage material. Thereafter, the $\mathrm{NO}_{\mathrm{x}}$ component and the oxygen contained in the exhaust gas are selectively reacted and converted into $\mathrm{N}_{2}$ and $\mathrm{H}_{2} \mathrm{O}$. SCR has better purifying ability and stable purifying performance than LNT, but if the proper injection of urea water is not controlled according to the engine condition, unreacted ammonia is discharged, causing secondary pollutants. On the other hand, because nitrogen oxide is very sensitive to high temperature, it is also important to lower the temperature of the exhaust gas. To reduce this, SCR and coolers were introduced. This study aims to develop a technology to improve the $\mathrm{NO}_{\mathrm{x}}$ reduction efficiency when applying SCR to reduce the nitrogen oxides generated by using methane gas in biogas engine.

\section{Experiment}

\subsection{Experimental set up}

Fermentation of foods generated from wastes generates biogas stored in storage tanks and then sulfuric acid of less than 10ppm is produced through a desulfurization facility and supplied to the engine. The engine applied is $350 \mathrm{KW}$ diesel engine, which was used for biogas, and the actual output is $200 \mathrm{KW}$. SCR was applied as a post-treatment device, and a De-NOx system equipped with a thermostat that lowers the temperature of exhaust gas from the $200 \mathrm{KW}$ engine by using a gas cooler at a temperature of about $400{ }^{\circ} \mathrm{C}$. A detailed schematic is shown in [Figure 1]. An SCR device is introduced to remove nitrogen oxides contained in the exhaust gas emitted from the generator. In order to reduce $\mathrm{NO}_{\mathrm{x}}$ through the SCR device, the optimum urea water and the optimal amount of air stored in the urea water storage tank are injected from the front end of the SCR through the urea water injection module through the urea water injection system. The injected urea water reduces nitrogen oxides by reducing the $\mathrm{NO}_{\mathrm{x}}$ contained in the exhaust gas. Excessive injection of urea can induce fine dust, so optimal urea injection technology is important. In order to reduce nitrogen oxide in the commercial generator $(200 \mathrm{KW})$, the nitrogen oxides were measured after the SCR was installed, and the temperature, pressure and nitrogen oxides concentration before and after the exhaust manifold measured according to the measurement conditions. 


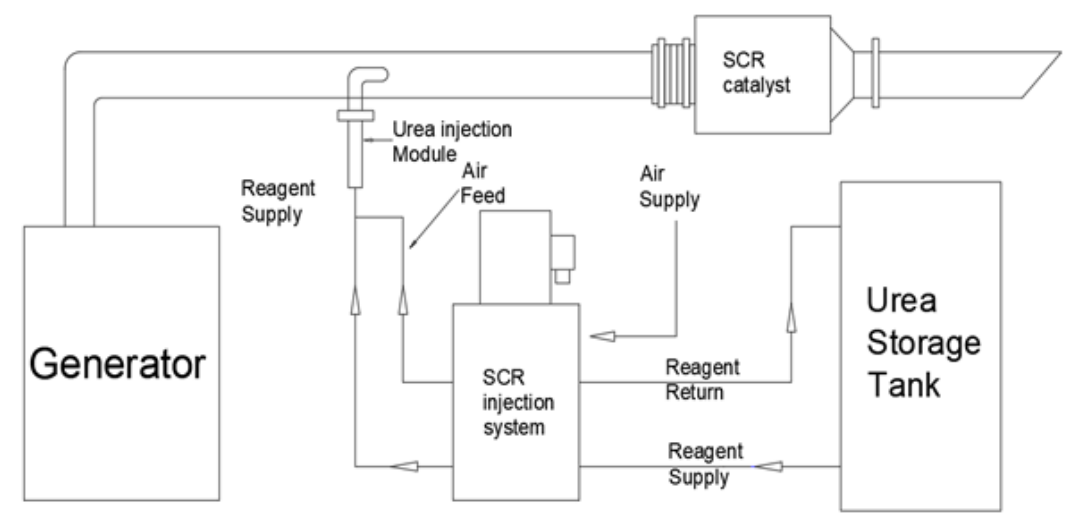

Figure 1. Schematic diagram for over-all emission reduction system

\subsection{Biogas fuel composition}

The components of biogas fuel generated from food waste used as fuel are shown in the [Table 1] after desulfurization of biogas.

Table 1. Biogas fuel property and composition

\begin{tabular}{|c|c|c|c|}
\hline \multicolumn{2}{|c|}{ Property of composition } & Unit & Index \\
\hline \multicolumn{2}{|c|}{ Gas amount } & $\mathrm{Nm}^{3} / \mathrm{h}$ & 854 \\
\hline \multicolumn{2}{|c|}{ Temperature } & ${ }^{\circ} \mathrm{C}$ & 35 \\
\hline \multicolumn{2}{|c|}{ Pressure } & $\mathrm{mmAq}$ & 1500 \\
\hline \multirow{4}{*}{$\begin{array}{c}\text { Gas } \\
\text { composition }\end{array}$} & $\mathrm{CH} 4$ & $\%$ & 64.81 \\
\hline & $\mathrm{H}_{2} \mathrm{O}$ & $\%$ & 0.93 \\
\hline & $\mathrm{O}_{2}$ & $\%$ & 0.27 \\
\hline & $\mathrm{CO}_{2}$ & $\%$ & 33.98 \\
\hline
\end{tabular}

\subsection{SCR Reaction Process}

Urea liquid is injected into $\mathrm{NO}_{\mathrm{x}}$ contained in the exhaust gas and converted into harmless $\mathrm{N}_{2}$ and $\mathrm{H}_{2} \mathrm{O}$. The reaction process is as follows [Figure 2]. After fermenting the food wasted, the sulfur contained in 3 4ppm is desulfurized and the generated biofuel is used as generator fuel. At this time, the exhaust gas discharged from the manner folder is sent to the DOC catalyst after lowering the exhaust temperature through a cooler and a fan. Purification efficiency of nitrogen oxide contained in exhaust gas is improved by injecting urea using metering pump before SCR catalyst and the process was shown in [Figure 3]. When lowsulfur (3-4 ppm) biogas obtained from food waste is supplied to the bio-engine, the engine is operated and the exhaust gas is emitted. In order to reduce the exhaust gas, harmful emissions are reduced by sequentially passing through DOC, SCR, and AOC catalysts. Among them, AOC (Ammonia Oxidation Catalyst) is a post-treatment device to prevent urea water remaining after urea water is injected into the SCR and reduced. In addition, a gas cooler was installed in front of the DOC (Diesel Oxidation Catalyst) to reduce the exhaust gas temperature. 


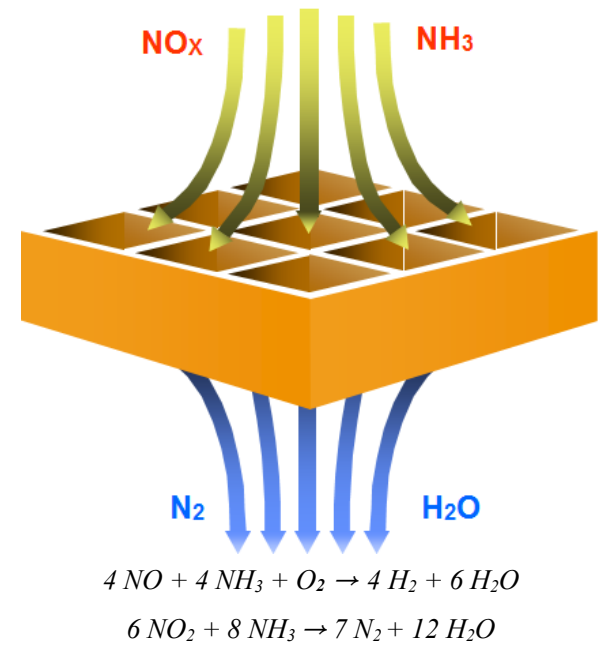

Figure 2. Chemical reaction process in SCR catalyst

\section{Experimental results}

\subsection{Urea liquid consumption}

In order to supply urea liquid, a quantitative flow pump is used, which is a pressure controlled pump. The Y-axis represents the flow rate supplied at the flow rate $(\mathrm{cc} / \mathrm{min})$, and the $\mathrm{X}$-axis represents the flow rate along the scale by dividing the mechanical flow control of the pump by 4 scales and shown in [Figure 4]. In the generator capacity of 200KW, the exhaust temperature was $300^{\circ} \mathrm{C}$, and the proper urea liquid supply amount was $15 \mathrm{cc} / \mathrm{min}$ with the frequency of $30 \mathrm{~Hz}$ and the scale fixed at 2.5 [Table 2].

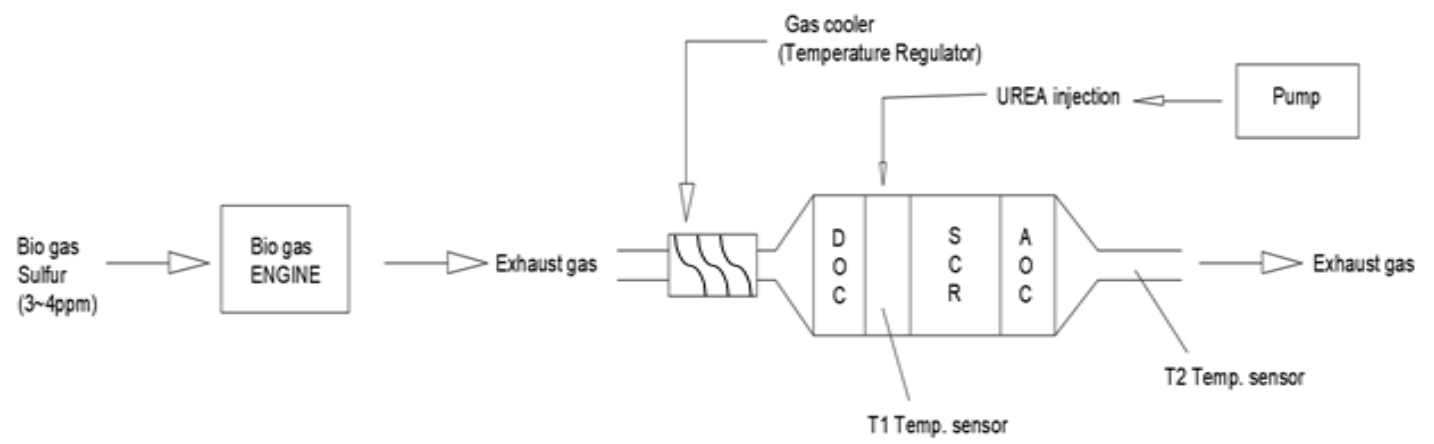

Figure 3. Purification process from SCR catalyst

The experiment was carried out to measure the generation of nitrogen oxide after installing SCR to reduce nitrogen oxide in commercial generator $(200 \mathrm{KW})$, and to measure the temperature, pressure and concentration of nitrogen oxide before the after the exhaust manifold according to the measurement conditions. It was necessary to confirm the presence of muffler as a factor that could affect the back pressure among the measurement conditions. 
And to reduce the exhaust gas temperature, fan and urea liquid method were applied, and the experimental conditions were separated for the application of urea liquid according to SCR application. The experiment was conducted several times in order to create an optimal temperature condition with the maximum purification efficiency. The temperature and pressure are important parameters for exhaust gas purification in the front and near stages of SCR device, a nitrogen oxide reduction device, and the nitrogen oxide was measured at $190 \mathrm{ppm}$. The optimal cooling temperature is realized at $300 \sim 350^{\circ} \mathrm{C}$.

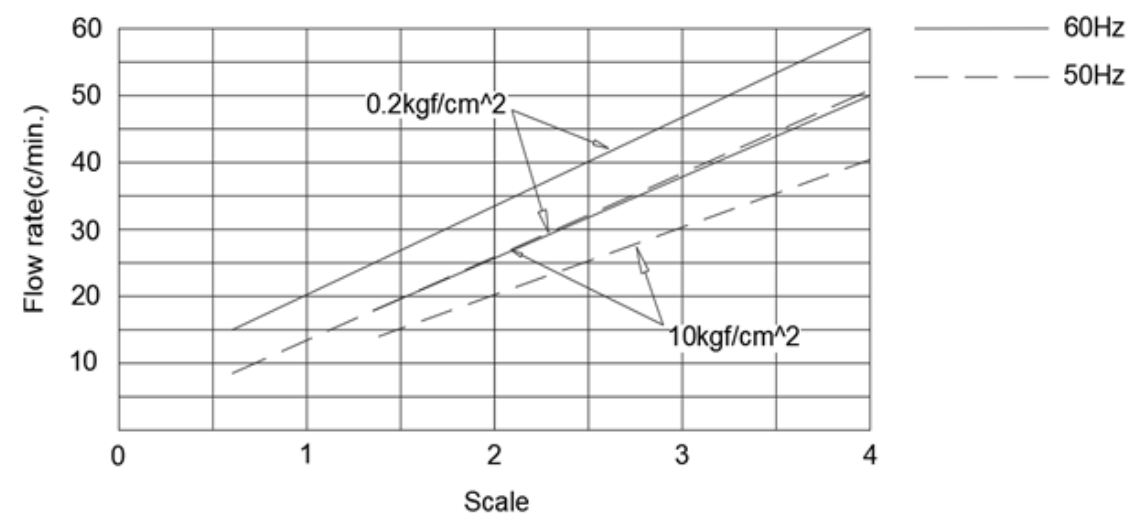

Figure 4. Flow rate of urea liquid by using a quantitative flow pump at $50 \mathrm{~Hz}$ and $60 \mathrm{~Hz}$

Table 2. Urea consumption by engine load

\begin{tabular}{|c|c|c|c|c|}
\hline $\begin{array}{c}\text { Engine Load } \\
(\mathrm{KW})\end{array}$ & Temp. $\left({ }^{\circ} \mathrm{C}\right)$ & Cycle $(\mathrm{Hz})$ & Scale & $\begin{array}{c}\text { Urea amount } \\
(\mathrm{cc} / \mathrm{min})\end{array}$ \\
\hline 200 & 300 & 30 & 2.5 & 15 \\
\hline
\end{tabular}

\subsection{Effect of NOx reduction by applying SCR, Fan and Cooler}

The exhaust temperature of $200 \mathrm{KW}$ bio-engine is $400{ }^{\circ} \mathrm{C}$ and the nitrogen oxide concentration at that time was $190 \mathrm{ppm}$. As a result of applying the cooler and SCR device, the temperature dropped to $360^{\circ} \mathrm{C}$ and the nitrogen oxide concentration at that time was $70 \mathrm{ppm}$. As a result, the temperature of nitrogen oxide concentration was $15 \mathrm{ppm}$ and the overall optimum purification efficiency was $92 \%$ and the summary was shown in [Table 3].

Table 3. Applying device and $\mathrm{NO}_{\mathrm{x}}$ reduction

\begin{tabular}{|c|c|c|}
\hline Applying Device & NOx Concentration (ppm) & Emission Temp. $\left({ }^{\circ} \mathrm{C}\right)$ \\
\hline Exhausted Emission & 190 & 400 \\
\hline SCR & 90 & 400 \\
\hline SCR +Cooler & 70 & 360 \\
\hline SCR+Cooler+Fan & 15 & 300 \\
\hline
\end{tabular}




\section{Conclusion}

The biogas engine was operated using biogas from food waste and SCR was introduced to reduce nitrogen oxides from biogas engines. It was found that the reduction efficiency of nitrogen oxides depends on the exhaust gas temperature and the amount of urea applied to the SCR. In order to apply SCR technology, the optimum urea injection amount was experimentally determined. In addition, since the amount of nitrogen oxides increased at high temperatures, a heat exchanger equipped with a cooling fan was installed to lower the temperature of the nitrogen oxides. At engine load $200 \mathrm{KW}$, the $\mathrm{NO}_{\mathrm{x}}$ reduction efficiency was about $90 \%$ at $300 \sim 350^{\circ} \mathrm{C}$. Injected urea liquid ere used to identify changes the purification efficiency that varied with injection flow rate. Therefore, it was confirmed that nitrogen oxide can be reduced by applying De-NOx system of SCR and a cooling device to commercial biogenerators.

\section{References}

[1] J. Huang and R. Crookes, "Spark-ignition engine performance with simulated bio-gas a comparison with gasoline and nature gas,” J. Inst. Energy, vol.71, no.21, pp.197-203, (1998)

[2] E. Porpatham, A. Ramesh, and B. Nagalingam, "Investigation of the effect of concentration of methane in biogas when used as a fuel for a spark ignition engine," Fuel, vol.87, no.8, pp.1651-1659, (2008)

[3] R. J. Crookes, "Comparative bio-fuel performance in internal combustion engines," J. of Biomass and Bioenergy, vol.75, no.45, pp.461-468, (2006)

[4] J. Huang and R. Crookes, "Assessment of simulated biogas as a fuel for the spark-ignition engine," Fuel, vol.77, no.15, pp.1793-1801, (1998)

[5] S. Bari, "Effect of carbon dioxide on the performance of biogas/diesel duel-fuel engine," Renewable energy, vol.9, no.72, pp.1007-1010, (1996)

[6] C. R. Stone and N. Ladommatos, "Design and evaluation of a fast burn spark-ignition combustion system for gaseous fuels at high compression ratios," J. of the institute of energy, vol.64, no.461, pp.201-211, (1991)

[7] P. G Tewari, J. P. Subrahmanyam, and M. K. Gajendrababu, "Experimental investigations on the performance characteristics of a producer gas fueled spark ignition engine," SAE paper 2001-01-1189, (2001)

[8] A. K. Agarwal and L. M. Das, "Biodiesel development and characterization for use as a fuel in compression ignition engines," Transactions of ASME, vol.123, no.7, pp.440-447, (2001)

[9] S. H. Kim, D. R. Lee, J. S. Ko, and D. G. Shin, "Spray hole structure optimization for increasing spray uniformity index in SCR system,” KSAE conference, pp.300-301, (2019)

[10] J. Lee, W. Kim, Y., Kim, S. Lee, S. Park, and K. Lee, "Experimental investigation on the relation between urea distribution at front of SCR catalyst and NOx reduction rate,” KSAE conference, pp.303, (2019) 